\title{
Intercalibration of classical and molecular techniques for identification of Alexandrium fundyense (Dinophyceae) and estimation of cell densities
}

\author{
Anna Godhe ${ }^{\mathrm{a}, *}$, Caroline Cusack $^{\mathrm{b}}$, John Pedersen $^{\mathrm{c}}$, Per Andersen ${ }^{\mathrm{c}}$, \\ Donald M. Anderson ${ }^{\mathrm{d}}$, Eileen Bresnan ${ }^{\mathrm{e}}$, Allan Cembella ${ }^{\mathrm{f}}$, Einar Dahl ${ }^{\mathrm{g}}$, \\ Sonja Diercks ${ }^{\mathrm{f}}$, Malte Elbrächter ${ }^{\mathrm{h}}$, Lars Edler ${ }^{\mathrm{i}}$, Luca Galluzzi ${ }^{\mathrm{j}}$, \\ Christine Gescher ${ }^{\mathrm{f}}$, Melissa Gladstone ${ }^{\mathrm{k}}$, Bengt Karlson ${ }^{1}$, David Kulis ${ }^{\mathrm{d}}$, \\ Murielle LeGresley ${ }^{\mathrm{m}}$, Odd Lindahl ${ }^{\mathrm{n}}$, Roman Marin ${ }^{\mathrm{o}}$, Georgina McDermott ${ }^{\mathrm{b}}$, \\ Linda K. Medlin ${ }^{\mathrm{f}}$, Lars-Johan Naustvoll ${ }^{\mathrm{g}}$, Antonella Penna ${ }^{\mathrm{p}}$, Kerstin Töbe ${ }^{\mathrm{f}}$ \\ ${ }^{a}$ Department of Marine Ecology, Marine Botany, Göteborg University, Box 461, SE 40530 Göteborg, Sweden \\ ${ }^{\mathrm{b}}$ The Martin Ryan Institute, National University of Ireland, Galway, Ireland \\ ${ }^{\mathrm{c}}$ Bio/consult A/S, Johs. Ewalds Vej 42-44, DK-8230 Åbyhøj, Denmark \\ ${ }^{\mathrm{d}}$ Woods Hole Oceanographic Institution, Biology Department, Woods Hole, MA 02543, USA \\ ${ }^{\mathrm{e}}$ Phytoplankton Ecology, Fisheries Research Services, Marine Laboratory, P.O. Box 101, \\ 375 Victoria Road, Aberdeen, AB11 9DB, United Kingdom \\ ${ }^{\mathrm{f}}$ Alfred Wegener Institute for Polar and Marine Research, Am Handelshafen 12, D-27570 Bremerhaven, Germany \\ ${ }^{\mathrm{g}}$ Institute of Marine Research, Flodevigen Marine Research Station, N-4817 HIS, Norway \\ ${ }^{\mathrm{h}}$ Deutsches Zentrum für Marine Diversitätsforschung, Forschungsinstitut Senckenberg, \\ Wattenweerstation Sylt, Hafenstr. 43, D-25992 List/Sylt, Germany \\ ${ }^{\mathrm{i}}$ Swedish Meteorological and Hydrological Institute, Doktorsgatan 9 D, SE 26252 Ängelholm, Sweden \\ ${ }^{\mathrm{j}}$ Centro di Biotecnologie, University of Urbino, via Campanella 1, 61032 Fano (PU), Italy \\ ${ }^{\mathrm{k}}$ Cawthron Institute, 98 Hali PB 2 Nelson, New Zealand \\ ${ }^{1}$ Swedish Meteorological and Hydrological Institute, Oceanographic Services, Nya Varvet 31, SE 42671 Västra Frölunda, Sweden \\ ${ }^{\mathrm{m}}$ Fisheries and Oceans Canada, Biological Station, 531 Brandy Cove Road, St. Andrews, NB E5B 2L9, Canada \\ ${ }^{\mathrm{n}}$ Kristineberg Marine Research Station, SE 45034 Fiskebäckskil, Sweden \\ ${ }^{\circ}$ Monterey Bay Aquarium Research Institute (MBARI), 7700 Sandholdt Road, Moss Landing, CA 95039-0628, USA \\ ${ }^{\mathrm{p}}$ Centro Biologia Ambientale, Istituto di Ecologia e Biologia Ambientale, University of Urbino, Viale Trieste 29661100 Pesaro, Italy
}

Received 20 February 2006; received in revised form 20 May 2006; accepted 13 June 2006

\begin{abstract}
A workshop with the aim to compare classical and molecular techniques for phytoplankton enumeration took place at Kristineberg Marine Research Station, Sweden, in August 2005. Seventeen different techniques - nine classical microscopic-based and eight molecular methods - were compared. Alexandrium fundyense was the target organism in four experiments. Experiment 1 was designed to determine the range of cell densities over which the methods were applicable. Experiment 2 tested the species specificity of the methods by adding Alexandrium ostenfeldii, to samples containing A. fundyense. Experiments 3 and 4 tested the ability of the methods to detect the target organism within a natural phytoplankton community. Most of the methods could detect
\end{abstract}

\footnotetext{
* Corresponding author. Tel.: +46 31773 2709; fax: +46 317732727.

E-mail address: anna.godhe@marbot.gu.se (A. Godhe).
} 
cells at the lowest concentration tested, 100 cells $\mathrm{L}^{-1}$, but the variance was high for methods using small volumes, such as counting chambers and slides. In general, the precision and reproducibility of the investigated methods increased with increased target cell concentration. Particularly molecular methods were exceptions in that their relative standard deviation did not vary with target cell concentration. Only two of the microscopic methods and three of the molecular methods had a significant linear relationship between their cell count estimates and the $A$. fundyense concentration in experiment 2, where the objective was to discriminate that species from a morphologically similar and genetically closely related species. None of the investigated methods were affected by the addition of a natural plankton community background matrix in experiment 3 . The results of this study are discussed in the context of previous intercomparisons and the difficulties in defining the absolute, true target cell concentration.

(C) 2006 Elsevier B.V. All rights reserved.

Keywords: Alexandrium fundyense; Alexandrium ostenfeldii; Intercalibration; Microscope; Molecular techniques

\section{Introduction}

Harmful algal blooms (HABs) are a global concern (Hallegraeff, 1995). Monitoring coastal waters for the presence of potentially harmful microalgae is therefore essential to assess the risk of bloom formation. Normally, this type of monitoring involves microscopic examination of plankton samples, and requires considerable taxonomic experience, because the identification is based on morphological characteristics and the species of interest frequently occur only as a minor component of the plankton community. Microscopicbased methods are therefore continuously fine tuned and modified (e.g., Fritz and Triemer, 1985; Klut et al., 1989; Elbrächter, 1994; Yamaguchi et al., 1995). During the last two decades, the desire to develop methods for rapid and specific identification with high sensitivity has motivated phycologists to explore the capability of molecular based techniques for species identification and enumeration (e.g., Anderson, 1995; Lim et al., 1996; Anderson et al., 1999; Haley et al., 1999; Bowers et al., 2000; Bolch, 2001). As a consequence, numerous methods have been employed in this field, each method with its own advantages and disadvantages.

In August 2005, an inter-comparison workshop on new and classical techniques for determination of the numerical abundance of harmful algal bloom (HAB) species was conducted at the Kristineberg Marine Research Station in Sweden. Scientists with experience in selected enumeration and identification techniques were invited to participate at the workshop. The overall objective was to compare cell count results using a variety of quantitative techniques that included both classical and molecular approaches. The target organism was Alexandrium fundyense Balech. Each participant was responsible for one or at most two specific enumeration methods, with the proviso that all methods to be compared should be fully developed and ready for operational use. Samples were provided to participants in a "blind" fashion, and only the experiment organisers were cognizant of the identity and composition of the samples distributed. Several experiments were conducted over the course of the workshop, each designed to evaluate a particular parameter or issue. The investigated parameters included the limit of detection, the specificity of the method, the accuracy and precision of the method, and the sensitivity to background species.

The specific objective of the first experiment was to determine the limits of detection of each method. The second experiment tested each method's ability to discriminate $A$. fundyense from the closely related species Alexandrium ostenfeldii (Paulsen) Balech et Tangen), known to co-occur in many locations. The third and the fourth experiment examined the accuracy of each counting method when the target organism is in the presence of different amounts of other phytoplankton and detritus (i.e., matrix effects).

Here, we present and compare the results of the intercomparison workshop.

\section{Material and methods}

\subsection{The methods}

Seventeen different methods for identification and enumeration of microalgae were tested (Table 1). Each participant conducted one or at most two methods. The classical microscopic methods were represented by techniques based on sedimentation (methods 1-3), filtration (methods 4-6), and different types of counting chambers or slides (methods 7-9). The molecular methods were represented by techniques based on polymerase chain reaction (PCR, method 10), wholecell ribosomal RNA (rRNA) hybridisation (methods 11-14), rRNA sandwich hybridisation (methods 15 and 17), and rRNA hybridisation (method 16). 
Table 1

Methods for identification and enumeration of Alexandrium fundyense

\begin{tabular}{ll}
\hline Method & Reference \\
\hline 1. Utermöhl sedimentation: lugol fixation & Utermöhl (1958) \\
2. Utermöhl sedimentation: formalin fixation, calcofluor staining & Utermöhl (1958), Fritz and Triemer (1985), \\
& Elbrächter (1994) \\
3. Settlement bottle & Raine et al. (1990) \\
4. Filtering and calcofluor staining & Andersen and Kristensen (1995) \\
5. Filtering on semitransperent filters & Fournier (1978) \\
6. Filtering and freeze filter transfer & Hewes and Holm-Hansen (1983), Rafuse (2004) \\
7. Sedgewick Rafter chamber & McAlice (1971) \\
8. Palmer-Maloney & Guillard and Sieracki (2005) \\
9. Haemocytometer & Guillard and Sieracki (2005) \\
10. Quantitative PCR & Galluzzi et al. (2004) \\
11. Whole-cell hybridisation assay with fluorescence microscopic detection A & Anderson et al. (2005) \\
12. Whole-cell hybridisation assay with fluorescence microscopic detection B & Miller and Scholin (1996, 2000) \\
13. Whole-cell hybridisation assay with fluorescence microscopic detection C & Groben and Medlin (2005) \\
14. Whole-cell hybridisation assay with TSA enhancement and ChemScan & Mignon-Godefroy et al. (1997), \\
& Schönhuber et al. (1999) \\
15. Sandwich hybridization assay with colourimetric detection & Scholin et al. (1996, 1997, 1999) \\
16. Hybridisation with microarray fluorescent detection & Metfies and Medlin (2004) \\
17. Sandwich hybridization with electrochemical detection & Metfies et al. (2005)
\end{tabular}

\footnotetext{
${ }^{a}$ Modifications: the method was adapted to primer sequences specific for A. fundyense (Dyhrman et al., 2006). PCR master mix containing SYBR Green (Diatheva srl). From day 2, samples were collected by filtration ( $3 \mu \mathrm{m}$ Millipore TSTP) instead of centrifugation.
}

\subsection{Experimental set up}

Cultures of A. fundyense (CA28, Woods Hole Oceanographic Institution, D.M. Anderson) and $A$. ostenfeldii (AOSH1, Alfred Wegner Institute, A. Cembella) were grown in $\mathrm{f} / 2$ (with no added silicate) medium (Guillard, 1975) at a salinity of 26 PSU, and K (with no silicate) medium (Keller et al., 1987) at a salinity of $30 \mathrm{PSU}$, respectively, at $10{ }^{\circ} \mathrm{C}$.

Cell densities of the A. fundyense and A. ostenfeldii stock cultures were estimated after fixing an aliquot in Lugol's solution. The concentrations were calculated as the average of three to six counts $(\geq 200$ cells counted) using $1 \mathrm{~mL}$ Sedgewick Rafter chambers (McAlice, 1971). This was carried out $1-2 \mathrm{~h}$ prior to the distribution of the samples for each experiment, and then $5 \mathrm{~mL}$ of this dilution was dispensed into $95 \mathrm{~mL}$ seawater samples (prefiltered or natural) in plastic $100 \mathrm{~mL}$ bottles. Five times $100 \mathrm{~mL}$ replicates of four sets of different sample types (S1-S4) were distributed on day 1 (D1) and $4 \times 100 \mathrm{~mL}$ replicates of four sets of different sample types (S1-S4) were distributed during days 2-4 (Table 2). All samples and the corresponding replicates were distributed at the same time every day (2000 h for experiments D2-D4) with the exception of the first day $(1100 \mathrm{~h})$. Participants were instructed to use their relevant standard procedure for their method. The output rates of the hybridisation with microarray fluorescence detection and the sandwich hybridisation with electrochemical detection (methods 16 and 17; Table 1) were limited, so only two samples with three replicates each were analysed by these two methods, per experiment.

To account for bias in the cell number in each sample, because of vegetative cell division, the interval between the time the target cell densities was estimated by the organisers and the distribution of the samples to the participants was kept as short as possible. Because vegetative cell division in dinoflagellates occurs predominantly during the morning hours (e.g., Yamaguchi, 1992; Machabée et al., 1994), the preparation and the distribution of samples were done at night, when possible.

In experiments D1 and D2 (Table 2), the Alexandrium cultures were diluted with filtered seawater (FSW, pore size $0.3 \mu \mathrm{m}$ ). In experiments D3 and D4, seawater (24 PSU, $18{ }^{\circ} \mathrm{C}$ ) from the Gullmarfjord (D3; $\mathrm{N} 58^{\circ} 15.9, \mathrm{E}^{\circ} 1^{\circ} 28.3$ ) and the Koljöfjord (D4; N58 ${ }^{\circ} 13.2$, E1 $\left.1^{\circ} 33.4\right)$ was collected at a depth of $5 \mathrm{~m}$ using a water sampler bottle and spiked with Alexandrium cells. The seawater was prefiltered with a $0.5 \mathrm{~mm}$ sieve to remove larger zooplankton and mixed in a $60 \mathrm{~L}$ carboy. The seawater in experiment D3 was also spiked with vertical plankton haul samples (mesh size $20 \mu \mathrm{m}$ ) containing an undefined plankton community. The salinity and temperature of the seawater used in the experiments was measured with a refractometer (Philips Analytical) and a thermometer, respectively. Chlorophyll $a(\operatorname{chl} a)$ 
Table 2

Experimental set up

\begin{tabular}{|c|c|c|c|}
\hline Experiment & Sample & Description & $\begin{array}{l}\text { Target cell number } \\
\left(\text { cells } \mathrm{L}^{-1}\right)\end{array}$ \\
\hline \multirow[t]{4}{*}{ D1 } & $\mathrm{S} 1$ & 100 A. fundyense cells $\mathrm{L}^{-1}$, diluted in FSW & 100 \\
\hline & $\mathrm{S} 2$ & 500 A. fundyense cells $\mathrm{L}^{-1}$, diluted in FSW & 500 \\
\hline & S3 & 1000 A. fundyense cells $\mathrm{L}^{-1}$, diluted in FSW & 1000 \\
\hline & S4 & 10,000 A. fundyense cells $\mathrm{L}^{-1}$, diluted in FSW & 10,000 \\
\hline \multirow[t]{4}{*}{$\mathrm{D} 2$} & $\mathrm{~S} 1$ & $90 \%$ A. fundyense, $10 \%$ A. ostenfeldii, diluted in FSW & 9000 \\
\hline & S2 & $70 \%$ A. fundyense, $30 \%$ A. ostenfeldii, diluted in FSW & 7000 \\
\hline & S3 & $30 \%$ A. fundyense, $70 \%$ A. ostenfeldii, diluted in FSW & 3000 \\
\hline & S4 & $10 \%$ A. fundyense, $90 \%$ A. ostenfeldii, diluted in FSW & 1000 \\
\hline \multirow[t]{4}{*}{ D3 } & $\mathrm{S} 1$ & Alexandrium spp. diluted in SW $\left(1.54 \mu \mathrm{g} \operatorname{chl} a \mathrm{~L}^{-1}(0.05)\right)^{\mathrm{a}}$ & 700 \\
\hline & $\mathrm{S} 2$ & Alexandrium spp. diluted in SW $\left(1.56 \mu \mathrm{g} \text { chl } a \mathrm{~L}^{-1}(0.05)\right)^{\mathrm{a}}$ & 700 \\
\hline & S3 & Alexandrium spp. diluted in SW $\left(1.71 \mu \mathrm{g} \text { chl } a \mathrm{~L}^{-1}(0.05)\right)^{\mathrm{a}}$ & 700 \\
\hline & S4 & Alexandrium spp. diluted in SW $\left(1.92 \mu \mathrm{g} \text { chl } a \mathrm{~L}^{-1}(0.05)\right)^{\mathrm{a}}$ & 700 \\
\hline \multirow[t]{4}{*}{ D4 } & S1 & 500 A. fundyense cells $\mathrm{L}^{-1}$, diluted in SW $\left(1.1 \mu \mathrm{g}\right.$ chl $\left.a \mathrm{~L}^{-1}\right)$ & 500 \\
\hline & $\mathrm{S} 2$ & 5000 A. fundyense cells $\mathrm{L}^{-1}$, diluted in SW $\left(1.1 \mu \mathrm{g}\right.$ chl $\left.a \mathrm{~L}^{-1}\right)$ & 5000 \\
\hline & S3 & 25,000 A. fundyense cells $\mathrm{L}^{-1}$, diluted in SW $\left(1.1 \mu \mathrm{g} \mathrm{chl} a \mathrm{~L}^{-1}\right)$ & 25,000 \\
\hline & S4 & 100,000 A. fundyense cells $\mathrm{L}^{-1}$, diluted in SW $\left(1.1 \mu \mathrm{g} \mathrm{chl} a \mathrm{~L}^{-1}\right)$ & 100,000 \\
\hline
\end{tabular}

FSW: filtered sea water, SW: sea water.

${ }^{\text {a }}$ Standard deviation $N=3$.

content was measured in seawater samples collected for the D3 and D4 experiments. One hundred mLs of seawater sample was filtered in triplicate onto $25 \mathrm{~mm}$ Whatman GF/F filters, and the chlorophyll extracted in $10 \mathrm{~mL}$ of $95 \%$ ethanol overnight at room temperature in a dark rotating box. A Turner fluorometer (Turner Designs Model $10 \mathrm{AU}$ ) was used to measure the fluorescence signal. Chl $a$ concentrations were calculated using equations in Parsons et al. (1984).

\subsubsection{Experiments}

2.2.1.1. Experiment 1 (D1). In experiment D1, the $A$. fundyense culture was diluted to an estimated final concentration of 100, 500, 1000 and 10,000 cells $\mathrm{L}^{-1}$ (target cell number) in FSW (S1-S4; Table 2). Five replicates (replicate volume $100 \mathrm{~mL}$ ) of each sample, S1-S4, were distributed randomly and analysed by 17 different identification and enumeration methods (Table 1).

For the subsequent experiments (D2-D4), four replicates of each sample (S1-S4) were distributed for analysis by each method.

2.2.1.2. Experiment 2 (D2). In experiment D2, cultured Alexandrium spp. (A. fundyense and A. ostenfeldii) were diluted in FSW to an estimated constant Alexandrium density of 10,000 cells $\mathrm{L}^{-1}$. The percentage compositions of $A$. fundyense to A. ostenfeldii in samples S1-S4 were $90 \%, 70 \%, 30 \%$ and $10 \%$, respectively (Table 2), with A. ostenfeldii comprising the remainder.
2.2.1.3. Experiment 3 (D3). In experiment D3, seawater was spiked with $A$. fundyense and $A$. ostenfeldii to an estimated final cell density of $700 \mathrm{~A}$. fundyense cells $\mathrm{L}^{-1}$ and $300 \mathrm{~A}$. ostenfeldii cells $\mathrm{L}^{-1}$ in all samples, S1-S4. In S1, these cells were added to unprocessed natural seawater (Table 2). In subsequent samples (S2-S4), the density of non-target species was increased by adding successively larger aliquots of the natural plankton community obtained from vertical plankton net hauls.

2.2.1.4. Experiment 4 (D4). In experiment D4, the $A$. fundyense culture was diluted to estimated final concentration of 500, 5000, 25,000, and 100,000 cells $\mathrm{L}^{-1}$ in natural seawater with a chl $a$ content of $1.1 \mu \mathrm{g} \mathrm{L}^{-1}$ (S1-S4; Table 2).

\subsection{Statistics}

Statistical analysis (means, variances, standard deviations, standard errors, confidence intervals), was carried out using the software SPSS (SPSS Inc.). The same software was used for analysis of variance (ANOVA) and regression analysis. Level of significance was set to ${ }^{*} p<0.05$.

One-way ANOVA was used to test if chl $a$ concentrations were significantly different between samples S1-S4 in experiment D3. The results generated by each method in experiment D3 from the different samples (S1-S4) were also tested by ANOVA. 
The functional relationship between the target cell concentrations and the observed results from the different methods was investigated by linear regression. Estimating the linear regression using a weighted least square compensated for the increasing variation between replicates with increasing target concentration. This implies that more precise observations, with less variability, get greater weight in determining the regression coefficient.

We wanted to investigate which method was closest to the target cell concentrations, and if the observed result of the methods deviated in a positive or negative way. Therefore, bias was calculated to estimate the divergence of the observed results from the target concentrations. Bias is the difference between the observed result and the target concentration. Mean bias is the average of the biases from the replicates. The deviation of observed results from the target concentration was expressed by displaying the average bias as a percentage of the target cell concentration.

\section{Results}

\subsection{Limits of detection}

The specific aim of experiment D1 (Table 2) was to determine the lower limit of detection of the methods examined (Table 1). The majority of the methods tested were able to detect cells at a predetermined target cell number of 100 cells L $^{-1}$ (Fig. 1). These methods included the sedimentation chamber and settlement bottle methods (methods 1-3), different filtering techniques (methods 4-6), and the whole-cell rRNA probe hybridisation assays with epifluorescent microscope detection (methods 11 and 12). Microscopic-based detection methods using small volumes $(\leq 1 \mathrm{~mL}$, methods 7-9) did not consistently detect cells at this concentration. The multiplication factor used to determine the final cell concentration in cells $\mathrm{L}^{-1}$ for the Sedgewick Rafter chamber and Palmer-Maloney slide methods (Fig. 1) was very high and therefore either overestimated or underestimated the final cell concentrations, with large variances. The mean observed cell number was 1000 cells $\mathrm{L}^{-1}$ with the Sedgewick Rafter chamber, with a standard deviation of 1225 . The mean observed cell number for the Palmer-Maloney slide method, which uses $1 / 10$ as much volume, i.e., $0.1 \mathrm{~mL}$, was 6000 cells L ${ }^{-1}$, with a standard deviation of 5477 . The haemocytometer (method 9) did not detect any cells when the target cell concentration was 100 cells $\mathrm{L}^{-1}$. In experiment D4, sample S4 (Table 2; Fig. 2), the estimated concentration of target cells was 100,000 cells $\mathrm{L}^{-1}$. This was the lowest limit of detection determined by the haemocytometer method during the workshop. Cells were not detected by this method at any other time during the workshop, even when the predetermined target cell concentration was 25,000 cells $\mathrm{L}^{-1}$ (the second highest cell concentration tested) in experiment D4, sample S3. The mean observed cell number $(N=4)$ generated by the haemocytometer in the D4 experiment, $\mathrm{S} 4$ sample (target cell number 100,000 cells $\mathrm{L}^{-1}$ ) was 125,000 cells $\mathrm{L}^{-1}$, displaying a standard deviation of 250,000.

Methods 13 and 14 (whole-cell hybridisation assay with fluorescence microscopic detection $\mathrm{C}$ and wholecell hybridisation assay with TSA enhancement and ChemScan) and 16 and 17 (hybridisation with microarray fluoescent detection and sandwich hybridisation with electrochemical detection) detected cells at

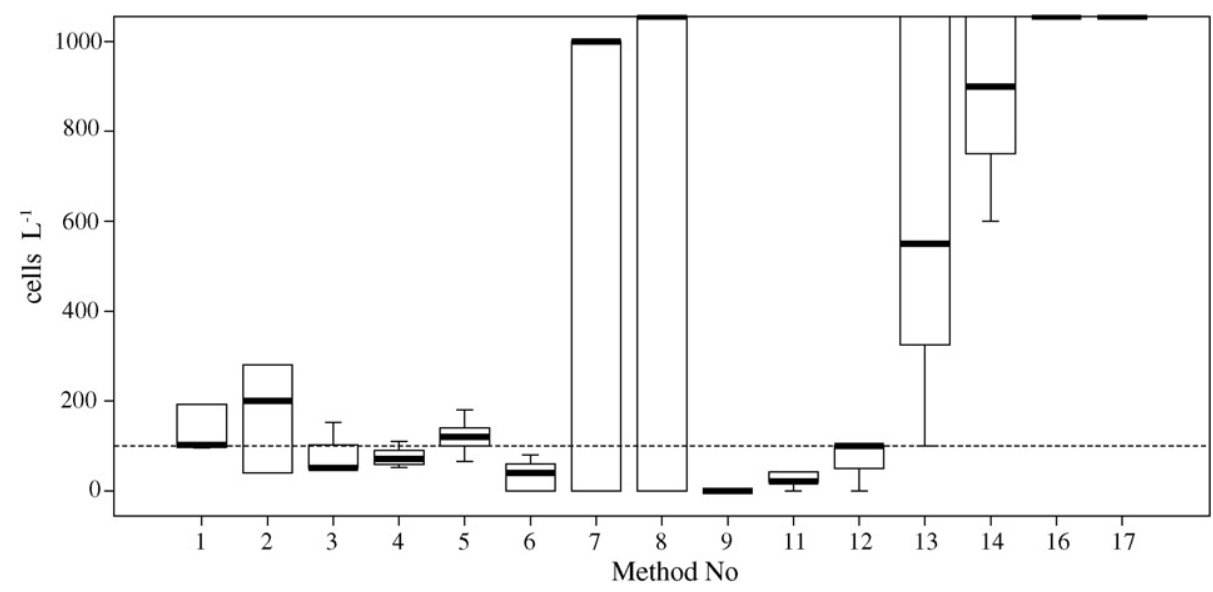

Fig. 1. Results from experiment D1, sample S1. Black bars indicate median value. Error bars represent maximum and minimum observed results. Boxes indicate standard error $(N=5$, for any deviation in number of replicate counted, see Table 3$)$. Target cell concentration $\left(100\right.$ cells $\left.\mathrm{L}^{-1}\right)$ is denoted by the checked line. No data was available for methods 10 and 15 (see text for further details). 


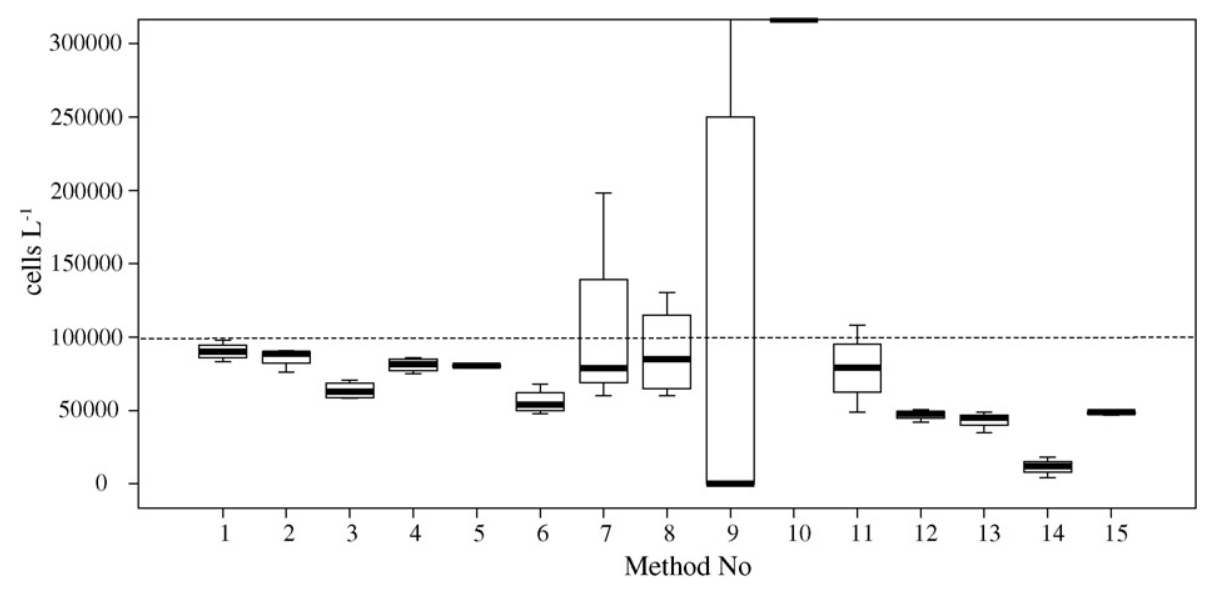

Fig. 2. Results from experiment D4, sample S4. Black bars indicate median value. Error bars represent maximum and minimum observed results. Boxes indicate standard error $(N=4$ for any deviation in number of replicate counted, see Table 3$)$. Target cell concentration $\left(100,000\right.$ cells $\left.\mathrm{L}^{-1}\right)$ is denoted by the checked line. No data was available for methods 16 and 17 .

100 cells $\mathrm{L}^{-1}$. The cell count recorded by these methods, however, deviated substantially from the target cell count, and the variance of the results from replicate samples was high (Fig. 1). Method 10 (quantitative PCR) and 15 (sandwich hybridisation assay with colourimetric detection) did not record the presence of cells at 100 cells $\mathrm{L}^{-1}$ because of logistical difficulties during the first experiment of the workshop. In subsequent experiments the two methods were able to detect the target species at low cell densities, e.g., in experiment D1 and D4, when the predetermined target cell concentration was 500 cells $\mathrm{L}^{-1}$, and in $\mathrm{D} 3$, when the target concentration was 700 cells $\mathrm{L}^{-1}$ (Fig. 3).

\subsection{Precision and reproducibility of the methods}

Two individual participants utilized Utermöhl sedimentation chambers (methods 1 and 2), but the volumes used (Table 3) and fixation methods were different (Table 1, references). Nevertheless, the precision and the reproducibility of the two Utermöhl techniques were similar. Results were consistently close to target cell numbers with high reproducibility (Figs. 2-6).

The settlement bottle (method 3) frequently underestimated the target cell number relative to the two other sedimentation techniques (Figs. 1 and 2, 6 and 7A). The reproducibility of the settlement bottle was also low

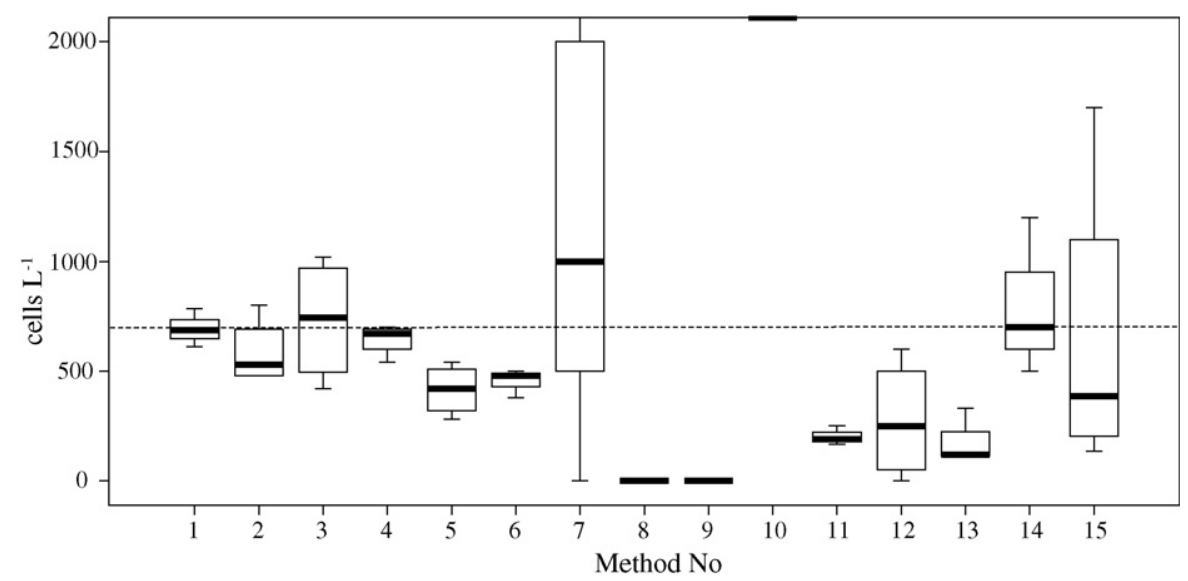

Fig. 3. Results from experiment D3, sample S2. Black bars indicate median value. Error bars represent maximum and minimum observed results. Boxes indicate standard error $(N=4$, for any deviation in number of replicate counted, see Table 3$)$. Target cell concentration $\left(700\right.$ cells $\left.\mathrm{L}^{-1}\right)$ is denoted by the checked line. No data was available for methods 16 and 17 . 
Table 3

Volume used, and number of replicates counted per sample and experiment by participating methods

\begin{tabular}{|c|c|c|c|c|c|}
\hline \multirow[t]{2}{*}{ Method } & \multirow[t]{2}{*}{ Volume used $(\mathrm{mL})$} & \multicolumn{4}{|c|}{ Output (maximum) } \\
\hline & & D1 (20) & D2 (16) & D3 (16) & D4 (16) \\
\hline 1. Utermöhl sedimentation: lugol fixation & $10.2-20.5$ & 20 & 16 & 16 & 16 \\
\hline 2. Utermöhl sedimentation: formalin fixation, calcofluor staining & 25 & 20 & 12 & 16 & 16 \\
\hline 3. Settlement bottle & 55 & 17 & 16 & 16 & 15 \\
\hline 4. Filtering and calcofluor staining & $50-100$ & 20 & 15 & 16 & 16 \\
\hline 5. Filtering on semitransperent filters & 50 & 20 & 16 & 16 & 16 \\
\hline 6. Filtering and freeze filter transfer & $20-50$ & 20 & 15 & 16 & 16 \\
\hline 7. Sedgewick Rafter chamber & 1 & 20 & 16 & 12 & 16 \\
\hline 8. Palmer-Maloney & 0.1 & 20 & 16 & 16 & 16 \\
\hline 9. Haemocytometer & 0.0018 & 20 & 16 & 16 & 16 \\
\hline 10. Quantitative PCR & 100 & 8 & 16 & 16 & 16 \\
\hline 11. Whole-cell hybridisation assay with fluorescence microscopic detection A & 50 & 20 & 15 & 15 & 16 \\
\hline 12. Whole-cell hybridisation assay with fluorescence microscopic detection B & 10 & 18 & 15 & 16 & 15 \\
\hline 13. Whole-cell hybridisation assay with fluorescence microscopic detection $\mathrm{C}$ & $18-100$ & 12 & 12 & 11 & 12 \\
\hline 14. Whole-cell hybridisation assay with TSA enhancement and ChemScan & $18-100$ & 4 & 6 & 12 & 12 \\
\hline 15. Sandwich hybridisation assay with colourimetric detection & 100 & 7 & 15 & 14 & 15 \\
\hline 16. Hybridisation with microarray fluorescent detection & 100 & 6 & 4 & 3 & 6 \\
\hline 17. Sandwich hybridisation with electrochemical detection & $93-100$ & 6 & 6 & 6 & 6 \\
\hline
\end{tabular}

compared to the other two sedimentation methods (methods 1 and 2) when target cell numbers were low (Figs. 3 and 4).

The cell counts generated from the three filter-based methods (methods 4-6; Table 1) frequently underestimated the target cell abundance (Figs. 1-3, 6 and 7A). The precision and reproducibility of the filtering and calcofluor staining method and the filtering on semitransparent filters method (methods 4 and 5) were similar (Figs. 1, 2, 4 and 6). The results from the filtering and freeze filter transfer method (method 6), in general, displayed a higher variance among replicates with a lower precision compared to the other two filtering methods (Figs. 1, 2, 6 and 7A).

The sedimentation chamber methods (methods 1 and 2) recorded cell concentrations closer to predetermined target cell concentrations than the filter-based methods (methods 4-6). The estimated cell counts of the filtering methods were lower. This trend was independent of the individual analyst performing cell enumeration (Figs. 1, 2, 6 and $7 \mathrm{~A}$ ).

The three counting chambers/slides (Sedgewick Rafter, Palmer-Maloney and haemocytometer; methods 7-9) used small sample volumes (Table 3). These methods, therefore, required a high density of target cells in order to yield high precision and adequate reproducibility. The counts reported by the Sedgewick Rafter chamber (method 7) were close to the target number only with cell concentrations $\geq 10,000$ cells $\mathrm{L}^{-1}$. A high variance was observed, however, even when the target cell concentration was
100,000 cells L ${ }^{-1}$ (Fig. 2). These three methods had a low precision when the target densities of $A$. fundyense cells were below 10,000 cells $\mathrm{L}^{-1}$ and reproducibility was low. At low target cell concentrations the relative standard deviation of methods 7 and 8 were close to or exceeded 100\% (Fig. 4).

The quantitative PCR (QPCR, method 10) had low precision, and repeatedly overestimated the target cell number (Figs. 2, 3, 6, 8 and 9B). The precision and the reproducibility of the method were independent of the target cell concentration. The relative standard deviations were ca. $25 \%$ irrespective of target cell densities (Fig. 4).

Three of the participants carried out whole-cell rRNA hybridisation assay using epifluorescent microscopic detection (methods 11-13). There were small variations in the respective operating procedures (Table 1, references). The reported cell counts of all three whole-cell hybridisation assays were lower than the target cell number (Fig. 7B). In general, the wholecell hybridisation assay A (method 11) gave estimates that were closest to the target cell number, whereas, whole-cell hybridisation assay $\mathrm{B}$ and $\mathrm{C}$ (methods 12 and 13) reported lower cell abundances (Figs. 2, 6, 7B and 9C). The reproducibility of the three whole-cell hybridisation assays with epifluorescent microscopic detection was, however, comparable and independent of target cell number (Fig. 4).

The whole-cell rRNA hybridisation with TSA enhancement and ChemScan detection (method 14; Table 1) had comparable cell counts to the whole-cell 

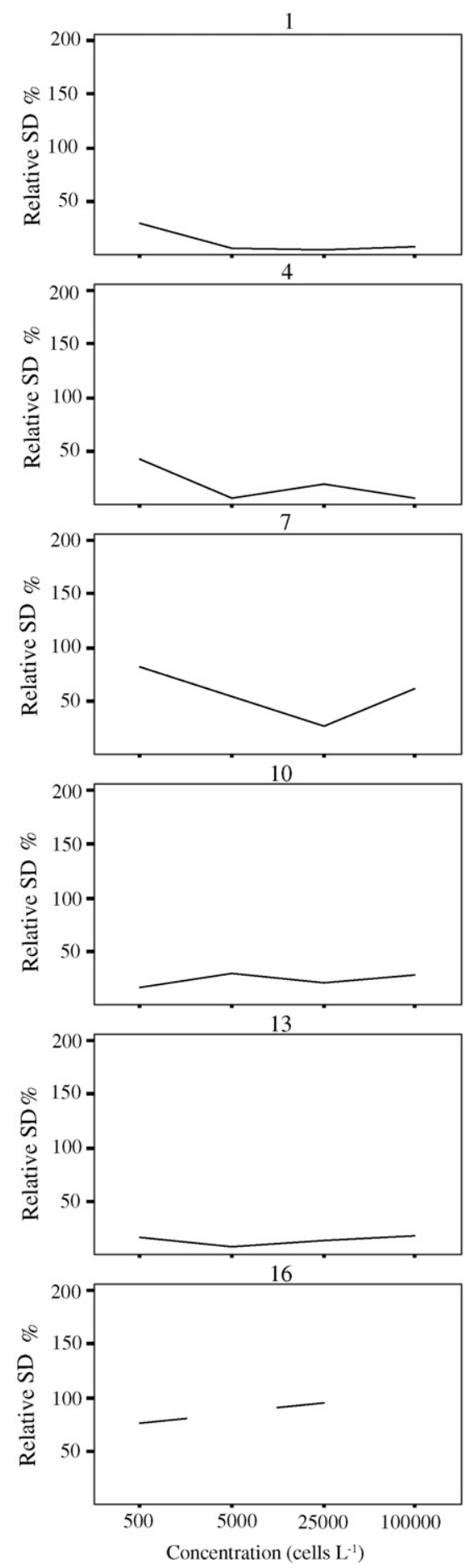
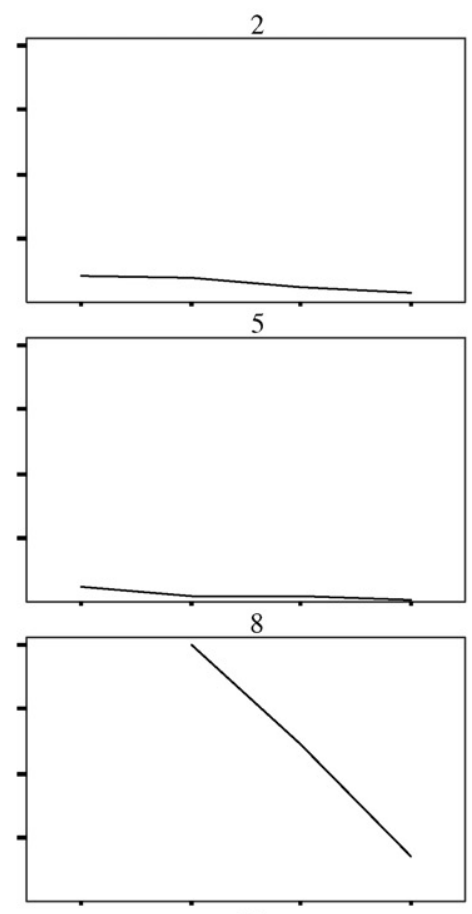

11

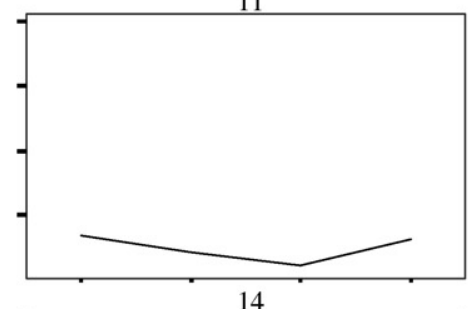

14

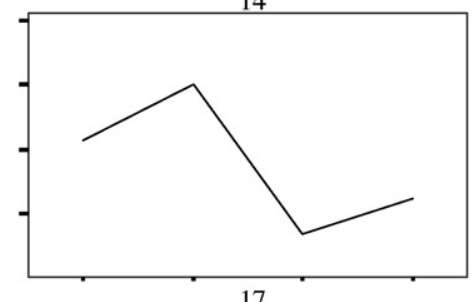

17

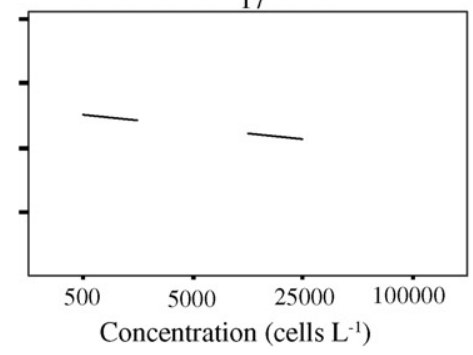

3
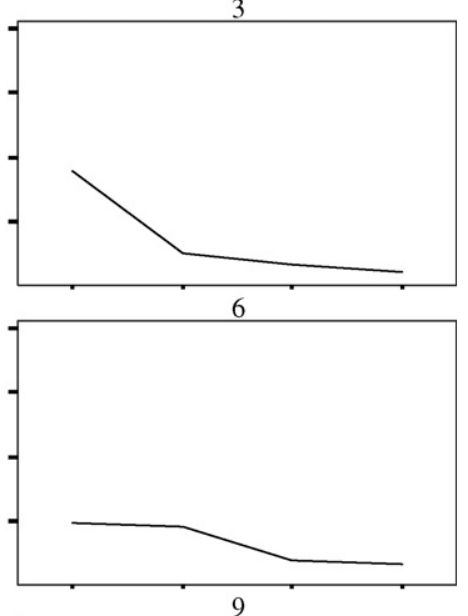

9

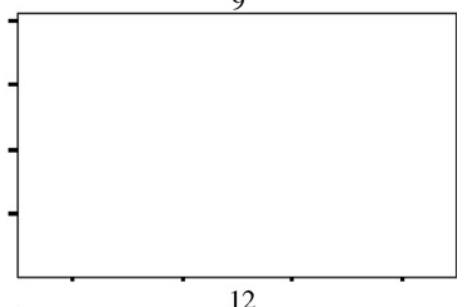

12
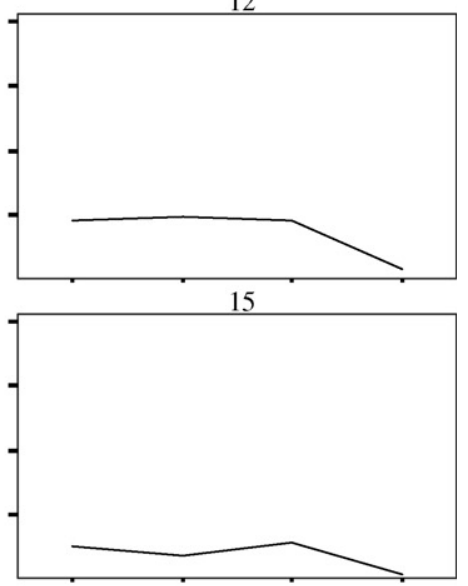

Fig. 4. Results from experiment D4, sample S1-S4. Target cell concentrations are displayed on the $x$-axis and relative standard deviation (S.D.)\% on the $y$-axis for methods 1-17. Cells were only recorded in the highest target concentration by method 9, thus no trend is displayed. Data points were only available for two samples (S1 and S3) for methods 16 and 17. See text for further details. 

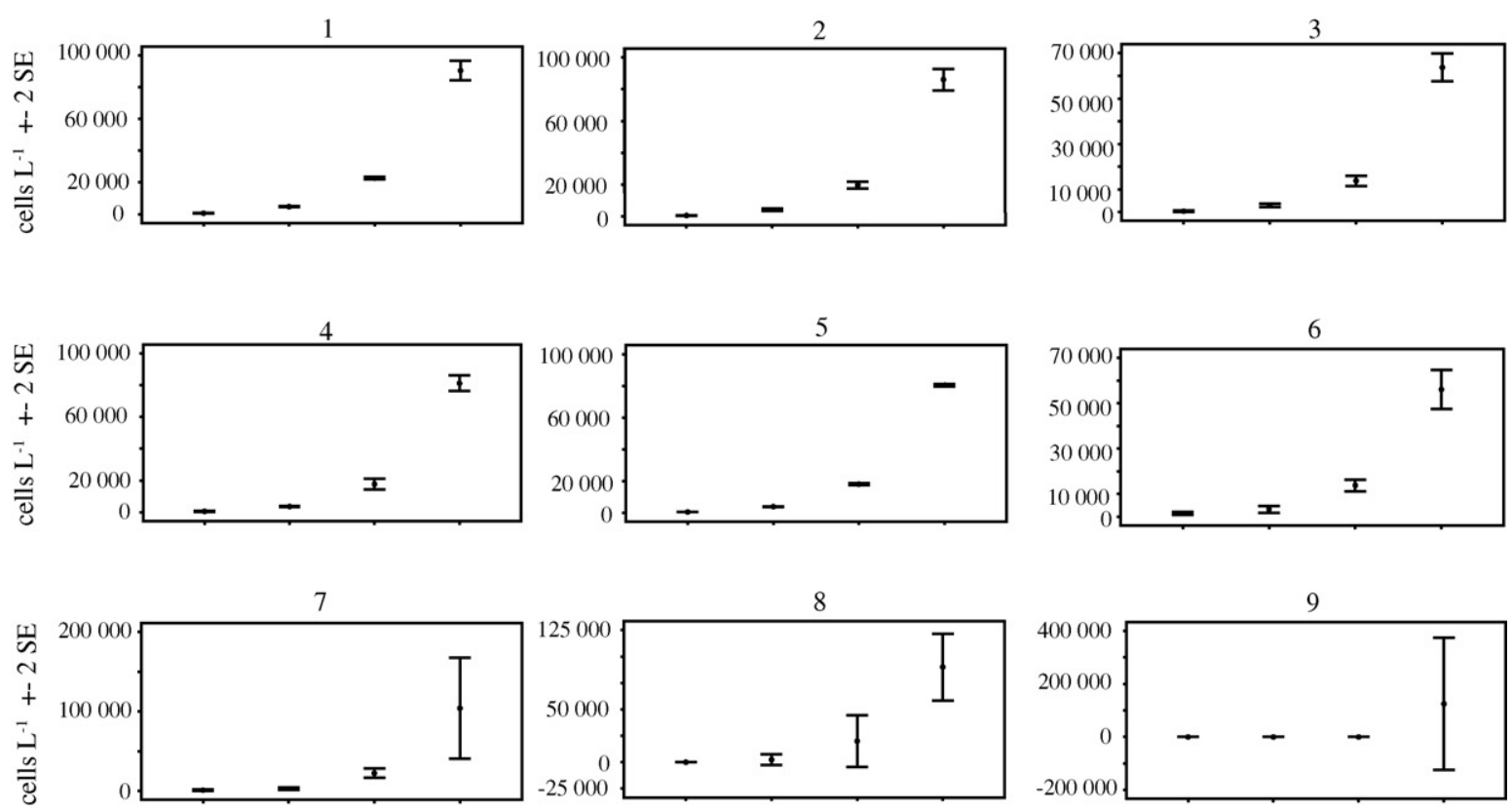

10
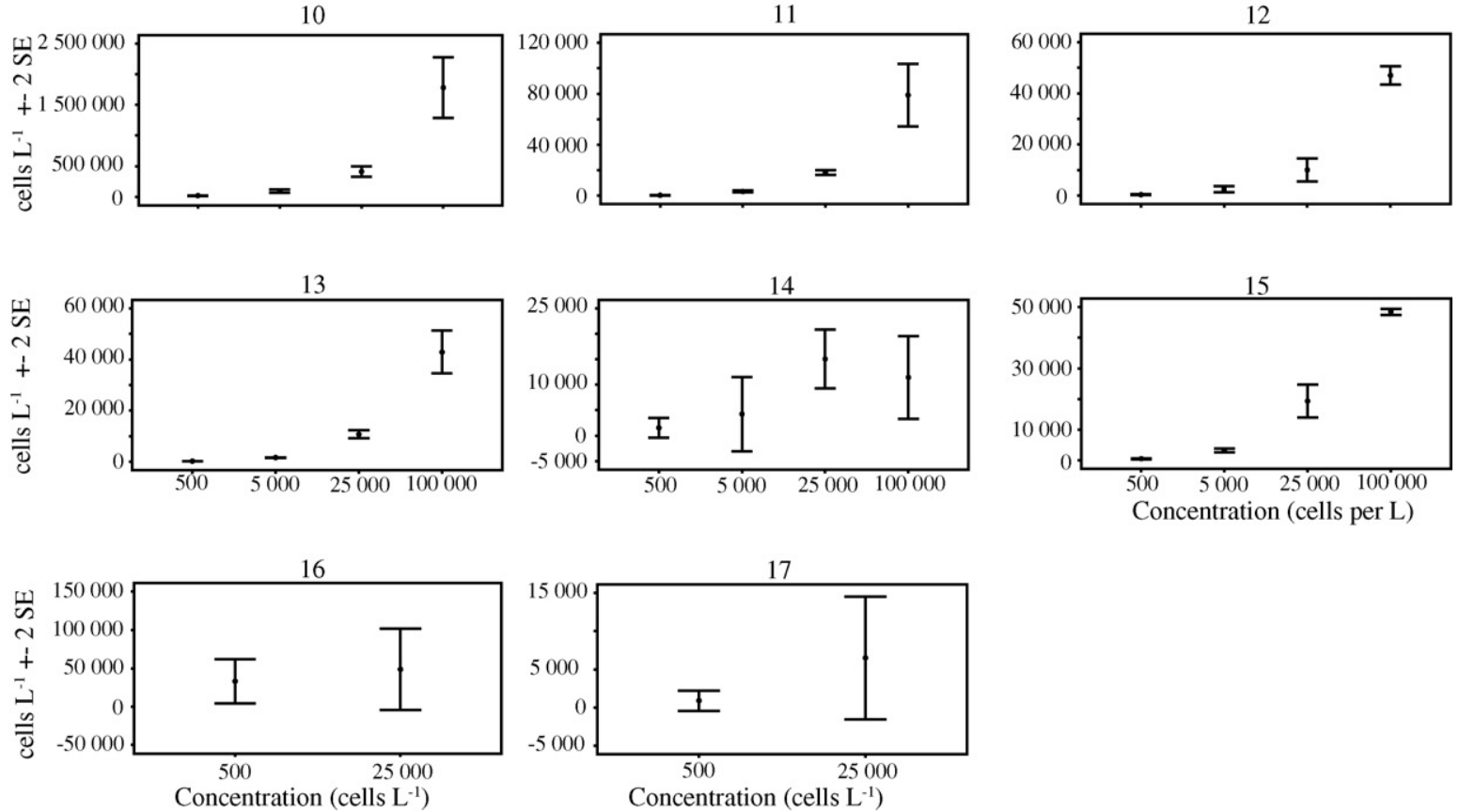

Fig. 5. Results from experiment D4, sample S1-S4. Target cell concentrations are displayed on the $x$-axis, and results $(N=4$, for any deviation in number of replicate counted, see Table 3 ) cells $\mathrm{L}^{-1} \pm 2 \times$ standard error (S.E.) on the $y$-axis for methods 1-17. Please note different scales on $y$-axis. Cells were only recorded in the highest target concentration by method 9. Data points were only available for two samples (S1 and S3) for methods 16 and 17. See text for further details.

hybridisation assays with epifluorescent microscopic detection (methods 11-13). The precision and reproducibility of method 14 was not as good as the other whole-cell hybridisation methods, however. In some of the experiments (e.g., D3), the precision of the ChemScan method improved and the reproducibility was similar to the other whole-cell methods (Fig. 3). In other experiments (e.g., D2 and D4), the cell counts 


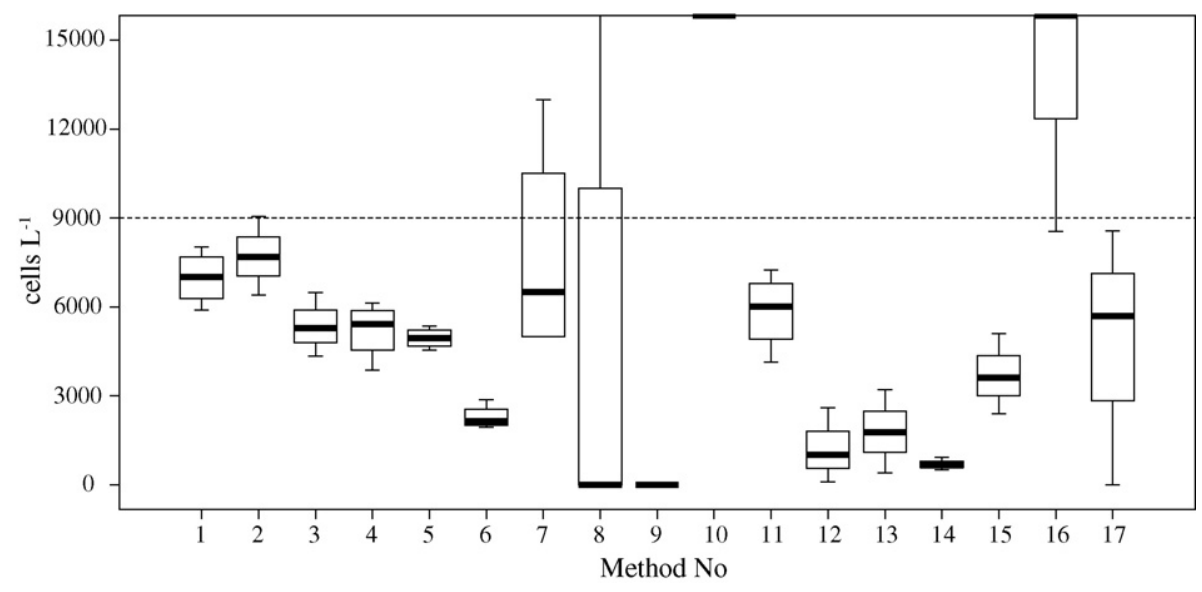

Fig. 6. Results from experiment D2, sample S1. Black bar indicate median value. Error bars represent standard deviation. Boxes indicate standard error $(N=4$, for any deviation in number of replicate counted, see Table 3$)$. Target cell concentration (9000 cells $\left.\mathrm{L}^{-1}\right)$ is denoted by the checked line.

reported by the ChemScan method were either overestimates or underestimates and large variances were observed (Figs. 4, 5 and 9C). The precision of the method was independent of the target cell concentration (Fig. 5).

Sandwich hybridisation with colorimetric detection (method 15; Table 1) underestimated the target cell number in many of the experiments (Figs. 2, 6, 7B and 9C). This method showed high reproducibility (Figs. 24 and 6), which was independent of target cell density (Fig. 5). In some experiments (e.g., D3), however, large variances were observed (Fig. 3).

The sample throughput of the hybridisation with microarray fluorescence detection and sandwich hybridisation with electrochemical detection (methods 16 and 17) was limited, and only two samples represented by three replicates could be analysed per experiment. Method 16 failed to analyse the three replicates per sample in experiment D2 and D3 (Table 3). In three of the samples analysed by method 17 , one replicate each had no cell record (data not shown). The hybridisation with microarray fluorescence detection (method 16) overestimated the target cell number in all experiments (Figs. 1, 6 and 8). The low precisions of these two methods (16 and 17) were independent of target cell numbers (Fig. 4). Because of lack of data, it is difficult to test precision and reproducibility of these methods, and further comparisons with other methods are not possible.

\subsection{Discrimination between closely related species}

The overall objective of experiment D2 was to see how well the methods being tested discriminated the target species $A$. fundyense from a morphologically similar and genetically related species, A. ostenfeldii.

For most of the microscopic based methods (methods 1 and 2, 5-8), the regression analysis of the target A. fundyense cell concentrations and the results of the methods, were not significant. The results were similar despite varying target cell concentrations (Fig. 9A). Methods 3 and 4 had a significant linear relation between the target cell concentration and the observed results. The mean cell number of these two methods (settlement bottle and filtering and calcofluor staining) increased proportionally as the target cell number increased (Fig. 9A). The target cell concentrations of S1-S2 were too low to be detected by the Palmer-Maloney slide method (method 8). The target cell concentrations of all the samples (S1-S4) were too low to be detected using the haemocytometer (method 9), and regression analysis was not carried out for this method.

Counts from the QPCR (method 10) overestimated the target cell number by a factor of 3-5 in all samples analysed (Fig. 9B), but the linear regression between the target cell concentration and the observed results of the QPCR was significant.

The regression between the target cell concentration and the cell counts of whole-cell hybridisation assay with epifluorescence microscopic detection A (method 11) was significant, whereas, the other two whole-cell hybridisation assays with epifluorescence microscopic detection (method 12 and 13) were not (Fig. 9C).

Results generated from the whole-cell rRNA hybridisation with TSA enhancement and ChemScan detection were difficult to analyse because of too few data points. Data from three replicates of two target 

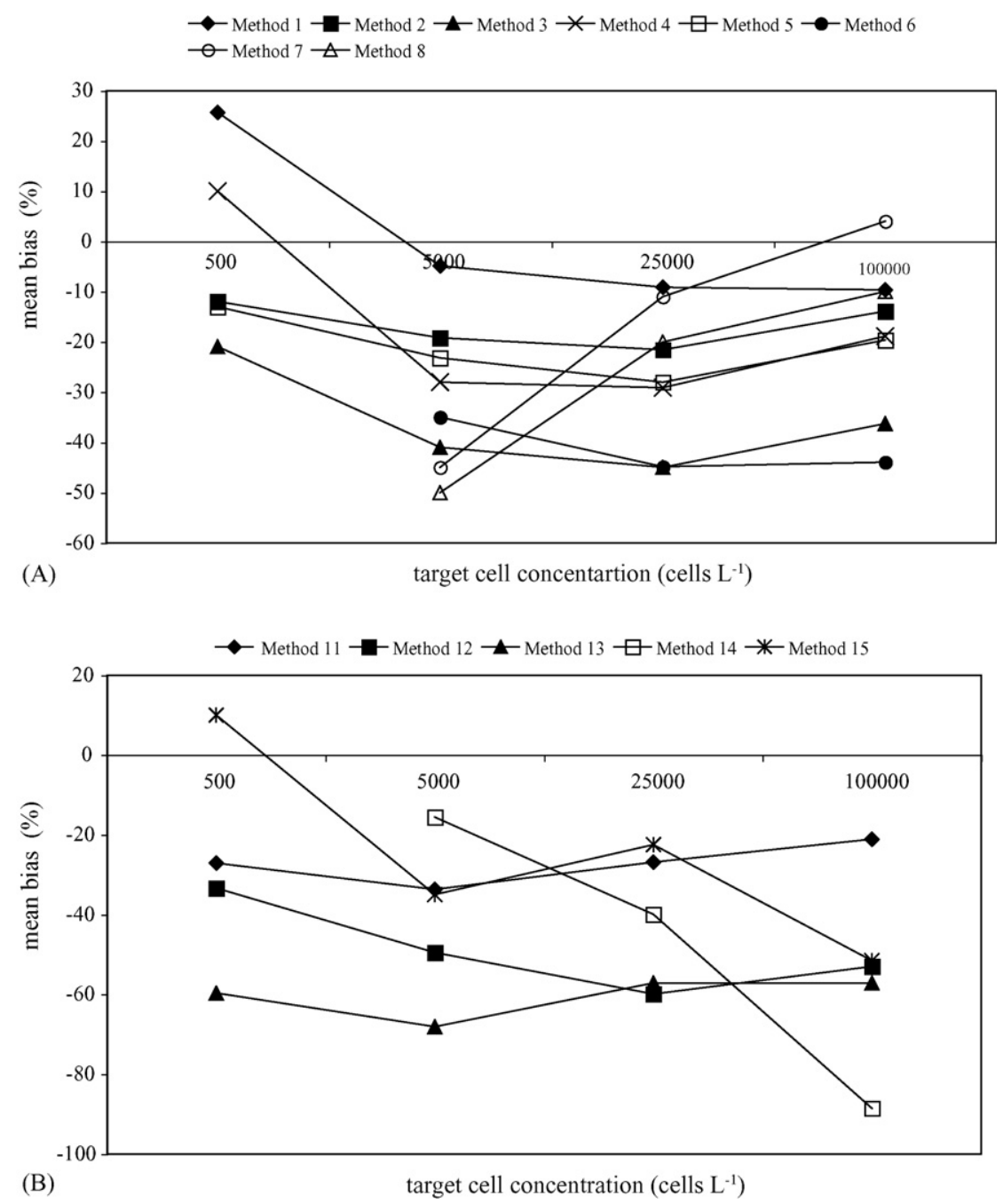

Fig. 7. Deviation of the observed results from the target concentrations in experiment D4. The deviation is expressed by displaying the average $(N=4$, for any deviation in number of replicate counted, see Table 3) bias as a percentage of the target cell concentration. Bias is the difference between the result and the target concentration. Please note different scales on $y$-axis. Error bars have been left out for clarity. (A) Microscopic methods: mean biases (\%) of methods 6-8 (S1) and 9 (S1-S4) exceed $\pm 100 \%$, and is not displayed. (B) Molecular methods: mean biases (\%) of method 10 (S1-S4), method 14 (S1), methods 16 and 17 (S1-S4) exceed $\pm 200 \%$, and is not displayed.

concentrations (S2 and S4) were provided from method 14. The mean values were much lower than target cell concentrations (Fig. 9C). The regression between the results of methods 14 and the target concentration was not significant.

The cell count of the sandwich hybridisation with colorimetric detection (method 15) underestimated the target $A$. fundyense cell concentrations, but the regression between the target cell concentrations and results was significant (Fig. 9C).

Results from the hybridisation with microarray fluorescent detection, and sandwich hybridisation with the electrochemical detection method (methods 16 and
17) were difficult to analyse because of too few data points. The cell counts of method 16 were overestimated relative to the target cell concentrations (Fig. 9B). Method 17 provided two mean values based on three different replicates for two of the target concentrations (Fig. 9B). The regressions between the results of methods 16 and 17 and the target concentration were not significant.

\subsection{Background species}

In experiment D3 the intention was to vary the background matrix with different densities of non-target 


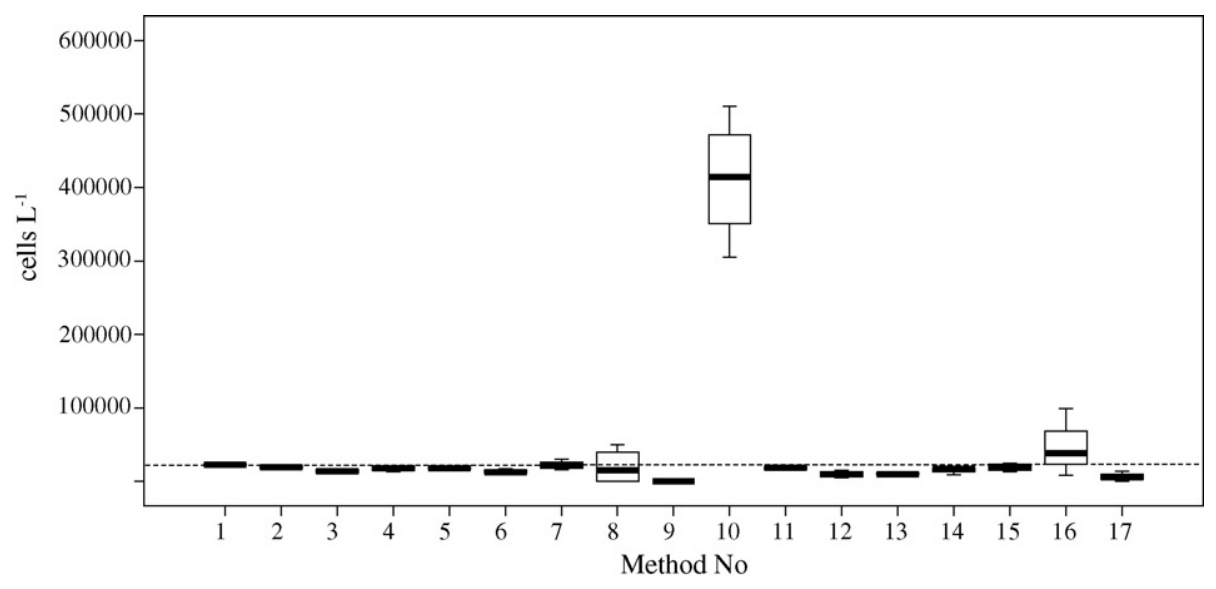

Fig. 8. Results from experiment D4, sample S3. Black bar indicate median value and error bars represent standard deviation. Boxes indicate standard error $(N=4$, for any deviation in number of replicate counted, see Table 3$)$. Target cell concentration $\left(25,000\right.$ cells $\left.\mathrm{L}^{-1}\right)$ is denoted by the checked line.

phytoplankton species and detritus. In sample S1, the chl $a$ concentration of the natural seawater used was $1.54 \mu \mathrm{g} \mathrm{L}^{-1}$ (Table 2). Additional background matrix was introduced to samples S2-S4 by pipetting an aliquot of plankton slurry from a plankton net hauled through the water column. Chlorophyll $a$ concentrations for the samples are presented in Table 2. The chl $a$ concentrations in samples S1 and S2 were not significantly different. The chl $a$ concentrations in S3 and S4 were significantly different from all other samples (data not shown). Despite the significantly higher chl $a$ concentration in samples S3 and S4 the outputs of all the methods (1-17) were not affected. The target cell concentrations were the same in all samples (S1-S4), i.e., 700 cells $\mathrm{L}^{-1}$. Results of cell counts from methods $1-17$ of the samples S1-S4 were not significantly different (data not shown).

\subsection{Number of replicates counted}

In all experiments, D1-D4, four different samples, $\mathrm{S} 1-\mathrm{S} 4$, were included. The samples varied in one specific parameter per experiment. The number of replicates was five in experiment D1, resulting in 20 replicates to analyse on day 1 . The subsequent experiments had four replicates per sample, i.e., 16 samples per day. The number of replicates counted per method and experiment is displayed in Table 3. The classical microscopic based methods (methods 1-9) required little time to set-up and were promptly ready to carry out analysis on the samples provided for experiment D1. The molecular based methods (methods 10-17) were slower to start, thus many replicates from the first experiment, D1, could not be analysed.

\subsection{Target cell concentration}

In Fig. 7, the results of the different methods relative to the target count is displayed. In 4 out of 45 recorded mean bias values for day $4 \mathrm{~S} 1-\mathrm{S} 4$, the observed result is overestimated. Forty-one out of 45 mean bias values are negative, and thus represent underestimated observed results.

\section{Discussion}

Comparisons on the efficiency of different identification and enumeration methods for phytoplankton have previously been conducted (e.g., Reckermann and Colijn, 2000; Reckermann et al., 2001; Savin et al., 2004). However, despite similarities in approaches or study objectives, the procedures followed differed and thus it is difficult to compare across studies. Accordingly, the results we present here are unique. In the literature, comparison of molecular and traditional methods for identification purposes are few, but available data suggests that differences are common (Savin et al., 2004; Anderson et al., 2005). During this workshop no single method could be judged the best, as many methods had their strengths as well as weaknesses.

Identifying and enumerating algae using a microscope requires considerable taxonomic experience, because the identification is based on morphological characters. The performance of an individual scientist conducting identification and enumeration of microalgae by molecular methods also requires experience. Probably, it is faster and easier to become competent with molecular methods than becoming competent with 
morphological identification. However, none of the tested methods are independent of the operator. Only one person conducted the methods tested during the workshop, and no information is available on operator variability. Presumably we would have introduced greater variance of the observed results if operator variability also was tested.
An absolute true cell concentration could not be specified for any experiment, sample or replicate. The most probable concentration of any sample will be the count given by the majority of the methods investigated, provided that there are no cell division or pipetting errors introduced while preparing and distributing samples to the participants. Despite these prerequisites,
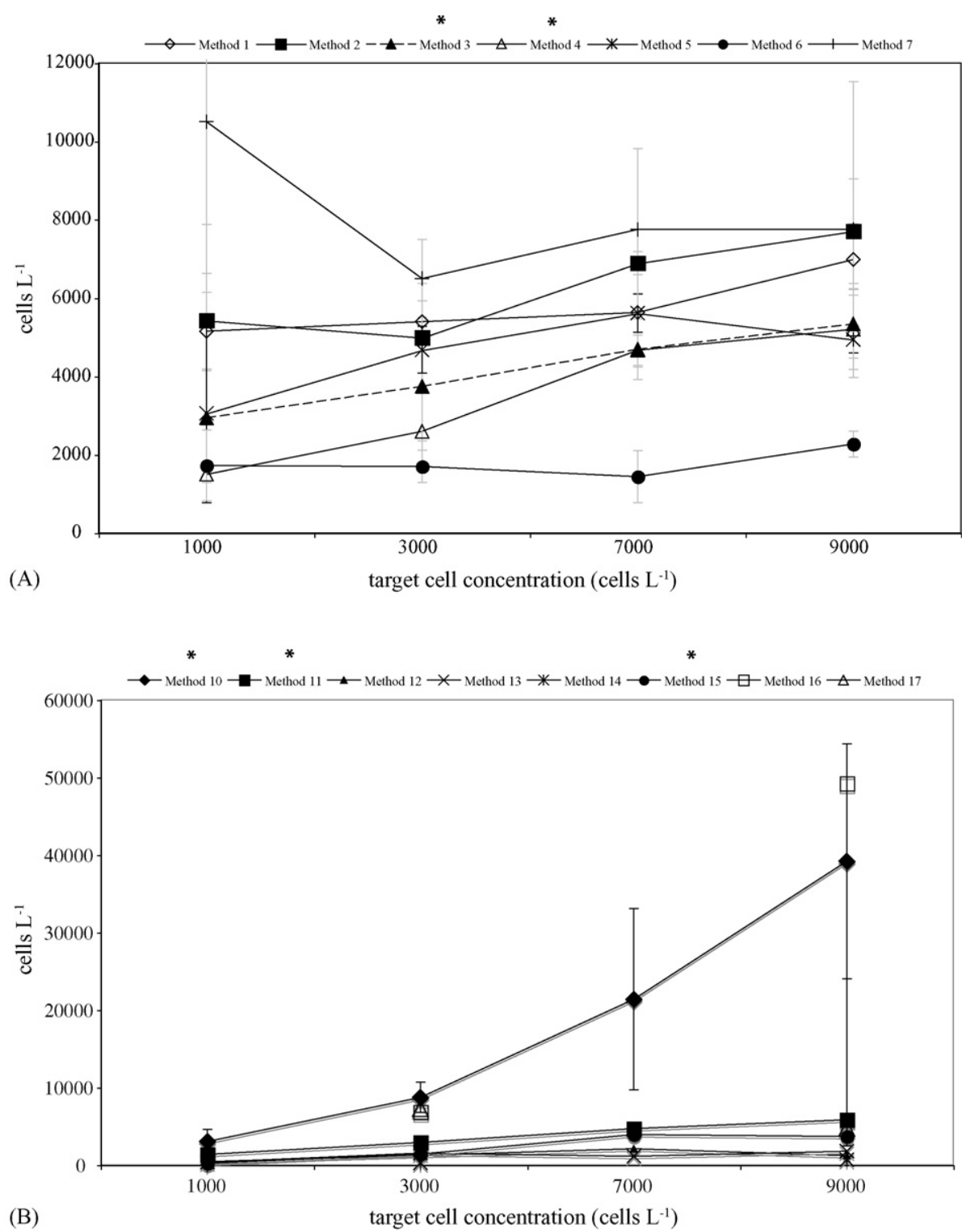

Fig. 9. Results from experiment D2. Significant regressions are denoted by $*$ above the methods. Error bars represent standard deviation $(N=4$, for any deviation in number of replicate counted, see Table 3). (A) Microscopic methods: results from methods 8 and 9 are not displayed due to too few data points. Error bars of method 7 (S1) exceed the diagram area. (B) Molecular methods: error bars are displayed only for method 10 and 16 . Error bars of method 16 (S4) exceed the diagram area. Results from methods 16 and 17 are available from concentration S2 and S4 only. A line does not connect these data points. (C) Molecular methods excluding methods 10, 16 and 17. Error bars represent standard deviation $(N=4$, for any deviation, see Table 3). Error bars of method 12 (S2 and S4) exceed the diagram area. Results from method 14 is available from samples S2 and S4 only. A line does not connect these data points. 


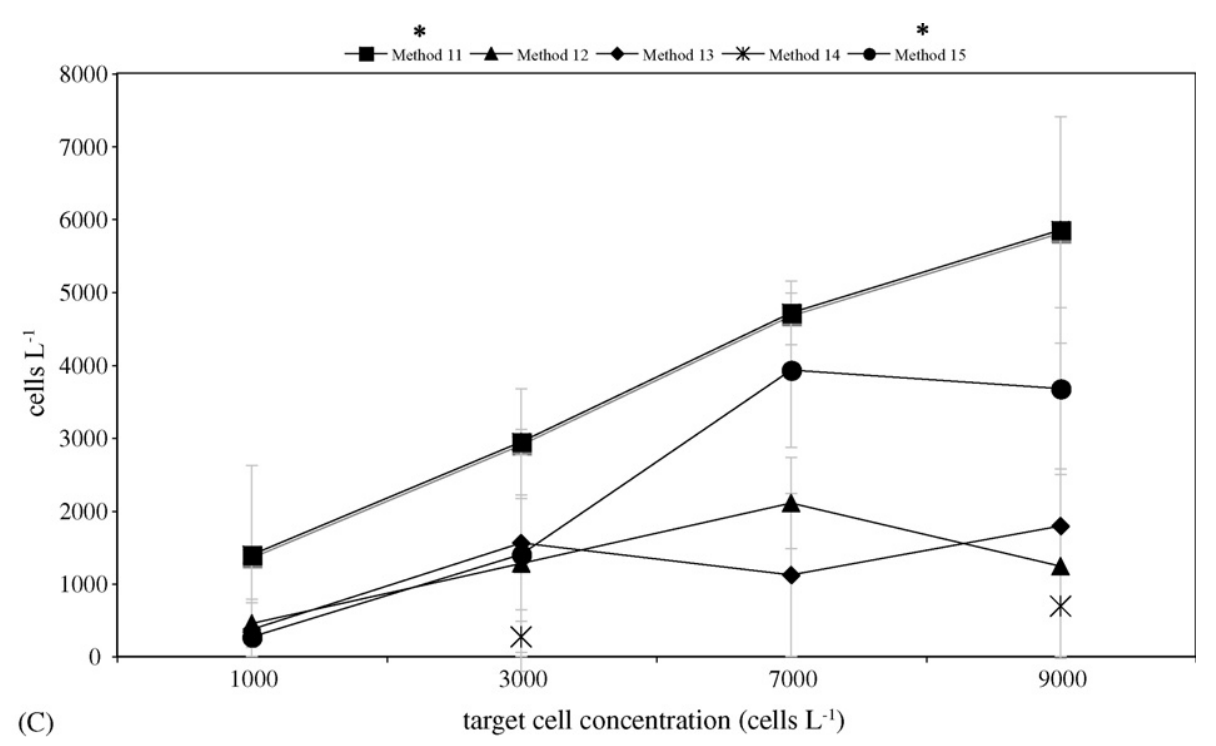

Fig. 9. (Continued).

target cell concentrations had to be estimated to permit comparisons of the different methods. The target cell concentration was estimated as an average of several counts of a dense (in the range of a million cells per litre) stock culture, using one of the methods investigated, i.e., Sedgewick Rafter chamber (method 7 ). This was considerably more dense than any of the samples given to the participants. The increase in precision with increased density of the target organism was a general result for all investigated methods. From this, and from examples in the literature (Andersen and Throndsen, 2003), it follows that the precisions of the target cell estimations were high. The majority of methods, underestimated the expected cell number, and therefore it is possible that the Sedgewick Rafter chamber overestimated the number of cells actually delivered to the participants. Methods 10 and 16 constantly overestimated the cell concentration, but this appeared to be the result of errors in the standard curves used to calculate the final cell concentrations in each sample analysed.

Errors may also be introduced if the culture of the target organism is not growing well. A culture that is not well maintained may present morphological characters that are not seen in natural samples. Moreover, significant variability in labelling intensity of rRNA probes because of algal growth stage has previously been demonstrated (Anderson et al., 1999; Peperzak et al., 2000). Consequently any identification based on morphological characters (methods 1-9) or rRNA probes (methods 11-17) can be affected by the condition of the culture. Despite effort in keeping cultures healthy, some participants, mainly those executing microscopic-based techniques, complained about the condition of the cultured target organisms.

In each experiment four samples, each represented by four or five replicates, were analysed. Consequently time was also a constraint. Thus, important procedures of the methodology normally practised when there is no shortage of time, had to be modified in order to complete all the replicates. For instance, when using the settlement bottle technique (method 3) it is recommended to count five transects in order to get an accurate estimation of the cell densities (Raine et al., 1990). The executer of this method counted only three strips along the base plate of the bottle when there was high concentration of target cells due to time constraints, which might have affected the results of the particular method.

The participants responsible for the molecular methods faced problems of more technical character. Many of the participants have reported that trials conducted prior to the workshop gave better precision, reproducibility and sensitivity. Many participants brought their own equipment, but some larger pieces of equipment were provided at site (e.g., centrifuges, hybridisation ovens, filtering manifolds). Generally, there were no problems with any of the equipments. One of the weaknesses of the molecular methods might be that they are very sensitive to small fluctuations in the operational procedure, and they perform best if they are conducted using a piece of equipment that is used for that particular purpose only. The hybridisation oven used for whole-cell hybridisation assay with fluores- 
cence microscopic detection A (method 11) was variable in temperature, and this might have influenced the reproducibility of that particular method. Slight procedural variation in protocols of molecular methods can also affect the output of similar techniques. Four participants conducted whole-cell rRNA hybridisation (methods 11-15), but the precision, the reproducibility, and the sensitivity to genetically close species were different. The better precision of whole-cell hybridisation assay with fluorescence microscopic detection A (method 11) as compared to whole-cell hybridisation assay with fluorescence microscopic detection B and C (methods 12 and 13), might be explained by the procedure of washing the filters in separate containers, which might have resulted in cell loss. Up to $30 \%$ cell loss has been noted where an analysis of the washing solution has been undertaken (A. Cembella, unpublished). Method 11 washed the cells on the filter manifold, but filtered a smaller volume than method 13, which may also have introduced an error. The precision and the reproducibility of whole-cell hybridisation assay with TSA enhancement and ChemScan (method 14) were not as good as the other whole-cell hybridisation methods. This was probably not due to the hybridisation as such, but caused by machine error. Some of the limitations and advantages of this method are related to the performance of the machine (Töbe et al., 2006).

Organizers predetermined the $100 \mathrm{~mL}$ sample volume distributed to the participants. Some methods, however, were better optimised for $100 \mathrm{~mL}$ samples. Others were not, and precision and reproducibility were affected. Method using small volumes did not obtain satisfactory results at low target cell concentrations, i.e., Sedgewick Rafter, Palmer-Maloney, and haemocytometer chambers. The quantitative PCR (method 10) used the entire volume, and the sandwich hybridisation assays and the hybridisation with microarray fluorescent detection (methods 15-17) used and required the entire volume distributed, i.e., $100 \mathrm{~mL}$. Detection of microalgal DNA by PCR is a very sensitive method (Godhe et al., 2002), and the sample volume should in theory not affect the results, provided that cells are retained during cell lysis and DNA extraction. However, in some of the hybridisation assays (methods 16 and 17), it is essential to begin with the correct amount of algal cells in order to obtain optimal RNA yield and purity with RNeasy columns (Metfies et al., 2005). For these assays, the volume provided might have been too small in the samples with very low target cell concentration, and the observed results may therefore have been affected.
The intention was that all methods should be fully developed and ready for operational use. Yet this was not the case. Some of the molecular methods were very new, and necessary tuning and adjustments were lacking, others, however, were well established, and gave acceptable results. Future workshops with the same perspective might be better in predicting reliability of some of the investigated methods.

\section{Conclusion}

Methods 1-8, 11-14 and 16 and 17 could detect cells at a concentration of 100 cells $\mathrm{L}^{-1}$, however the variance was high for methods 7 and 8,13 and 14, and 16 and 17 . The limit of detection was 100,000 cells $\mathrm{L}^{-1}$ for method 9. Methods 10 and 15 detected the target species at a cell target concentration of 500 cells $\mathrm{L}^{-1}$. The failure of methods 10 and 15 to detect cells at 100 cells $\mathrm{L}^{-1}$ was due to logistic problems.

In general, the precision and reproducibility of the investigated methods increased with increased target cell concentration. Many of the molecular methods were exceptions in that the relative standard deviation was not affected by the target cell concentration.

Only two of the microscopic methods (methods 3 and 4) and three of the molecular methods (methods 10 and 11 and 15) had a significant linear relation between their results and the cell target in experiment D2 when the objective was to discriminate the target species from a morphologically similar and genetically closely related species.

None of the investigated methods were affected by the extra addition of background matrix in experiment D3.

During this workshop the best precision and reproducibility was achieved by sedimentation chamber technique (methods 1 and 2). However, this technique was not as reliable when there were co-occurring species, which confused the observer. Microscopic discrimination of the two Alexandrium species was facilitated by calcofluor staining (method 4), which highlights minor morphologic differences, but it was also possible to discriminate between the species without this type of staining (method 3). However, molecular methods might be an even better choice when co-occurring, non-target species like A. ostenfeldii are a problem. QPCR (method 10), whole-cell hybridisation assay with fluorescence microscopic detection A (method 11) and sandwich hybridisation assay with colourimetric detection (method 15) proved sensitive enough for discrimination between two closely related species. 


\section{Acknowledgements}

This workshop was carried out with the support of the Marine Institute and the Marine RTDI (Research, Technology, Development and Innovation) Measure, Productive Sector Operational Programme, National Development Plan 2000-2006. Financial assistance was also received from the IOC (Intergovernmental Oceanographic Commission), Irish EPA (Environmental Protection Agency), Bord Iascaigh Mhara (The Irish Fisheries Board) and the Swedish Meteorological and Hydrographic Institute (SMHI). Participants travel and accommodation was generally supported from their individual financial research grants. Support has also been given by Formas (A.G.; 2005-255) and Swedish International Development Agency (A.G.; SWE 2002337). Travel support for one U.S. participant was provided by the Center for Sponsored Coastal Ocean Research (U.S. NOAA).[SES]

\section{References}

Andersen, P., Kristensen, H.S., 1995. Rapid and precise identification and counting of thecate dinoflagellates using epifluorescence microscope. In: Lassus, P., Arzul, G., le Denn, P.E., Gentien, P., Marcaillou, C. (Eds.), Harmful Marine Algal Blooms. Lavoisier Publishing, Paris, pp. 713-718.

Andersen, P., Throndsen, J., 2003. Estimating cell numbers. In: Hallegraeff, G.M., Anderson, D.M., Cembella, A.D. (Eds.), Manual on Harmful Marine Microalgae. IOC Manuals and Guides. UNESCO, Paris, pp. 99-129.

Anderson, D.M., 1995. Identification of harmful algal species using molecular probes: an emerging perspective. In: Lassus, P., Arzul, G., le Denn, P.E., Gentien, P., Marcaillou, C. (Eds.), Harmful Marine Algal Blooms. Lavoisier Publishing, Paris, pp. 3-13.

Anderson, D.M., Kulis, D.M., Keafer, B.A., Berdalet, E., 1999. Detection of the toxic dinoflagellate Alexandrium fundyense (Dinophyceae) with oligonucleotide and antibody probes: variability in labeling intensity with physiological condition. J. Phycol. 35, 870-883.

Anderson, D.M., Kulis, D.M., Keafer, B., Gribble, K., Marin, R., Scholin, C.A., 2005. Identification and enumeration of Alexandrium spp. from the Gulf of Maine using molecular probes. Deep Sea Res. II 52, 2467-2490.

Bolch, C.J., 2001. PCR protocol for genetic identification of dinoflagellates directly from single cysts and plankton cells. Phycologia 40, 162-167.

Bowers, H.A., Tengs, T., Glasgow, H.B., Burkholder, J.M., Rublee, P.A., Oldach, D.W., 2000. Development of real-time PCR assays for rapid detection of Pfisteria piscicida and related dinoflagellates. Appl. Environ. Microbiol. 66, 4641-4648.

Dyhrman, S.T., Erdner, D., La Du, J., Galac, M., Anderson, D.M., 2006. Molecular quantification of toxic Alexandrium fundyense in the Gulf of Maine using real-time PCR. Harmful Algae 5, 242250.

Elbrächter, M., 1994. Green autofluorescence-a new taxonomic feature for living dinoflagellate cysts and vegetative cells. Rev. Palaeobot. Palynol. 84, 101-105.
Fournier, R., 1978. Membrane filtering. In: Sournia, A. (Ed.), Phytoplankton Manual. Monographs on Oceanographic Methodology, vol. 6. UNESCO, Paris, pp. 108-112.

Fritz, L., Triemer, R.E., 1985. A rapid simple technique utilizing calcoflour white $\mathrm{M} 2 \mathrm{R}$ for the visualization of dinoflagellate thecal plates. J. Phycol. 21, 662-664.

Galluzzi, L., Penna, A., Bertozzini, E., Vila, M., Garcés, E., Magnani, M., 2004. Development of real-time PCR assay for rapid detection and quantification of Alexandrium minutum (a Dinoflagellate). Appl. Environ. Microbiol. 70, 1199-1206.

Godhe, A., Anderson, D.M., Rehnstam-Holm, A.-S., 2002. PCR amplification of microalgal DNA for sequencing and species identification: studies on fixatives and algal growth stages. Harmful Algae 1, 375-382.

Groben, R., Medlin, L.K., 2005. In situ hybridisation of phytoplankton using fluorescently-labelled rRNA probes. In: Zimmer, E., Roalson, E. (Eds.), Methods in Enzymology. Elsevier, San Diego, pp. 299-310.

Guillard, R.R.L., 1975. Culture of phytoplankton for feeding marine invertebrates. In: Smith, W., Chanley, M. (Eds.), Culture of Marine Invertebrate Animals. Plenum Press, New York, pp. 29-60.

Guillard, R.R.L., Sieracki, M., 2005. Counting cells in cultures with the light microscope. In: Andersen, R. (Ed.), Algal Culturing Techniques. Elsevier, London.

Haley, S., Cavender, J., Murray, T., 1999. Detection of Alexandrium tamarense by rapid PCR analysis. BioTechniques 26, 91-95.

Hallegraeff, G.M., 1995. Harmful algal blooms: a global overview. In: Hallegraeff, G.M., Anderson, D.M., Cembella, A.D. (Eds.), Manual on Harmful Marine Microalgae, vol. 33. IOC Manuals and Guides, Paris, pp. 1-22.

Hewes, D., Holm-Hansen, O., 1983. A method for recovering nanoplankton from filters for identification with the microscope: the filter-transfer-freeze (FTF) technique. Limnol. Oceanogr. 28, 389394.

Keller, M., Selvin, R., Claus, W., Guillard, R.R.L., 1987. Media for the culture of oceanic ultraphytoplankton. J. Phycol. 23, 633-638.

Klut, M.E., Stockner, J., Bisalputra, T., 1989. Further use of fluorochromes in the cytochemical characterization of phytoplankton. Histochem. J. 21, 645-650.

Lim, E.L., Caron, D.A., Delong, E.F., 1996. Development of field application of a quantitative method for examining natural assemblages of protists with oligonucleotide probes. Appl. Environ. Microbiol. 62, 1416-1423.

Machabée, S., Wall, L., Morse, D., 1994. Expression and genomic organization of a dinoflagellate gene family. Plant Mol. Biol. 25, 23-31.

McAlice, B., 1971. Phytoplankton sampling with the SedgewickRafter cell. Limnol. Oceanogr. 16, 19-28.

Metfies, K., Medlin, L.K., 2004. DNA microchips for phytoplankton: the fluorescent wave of the future. Nova Hedwiga 79, 321-327.

Metfies, K., Huljic, S., Lange, M., Medlin, L.K., 2005. Electrochemical detection of the toxic dinoflagellate Alexandrium ostenfeldii with a DNA-biosensor. Biosens. Bioelectron. 20, 1349-1357.

Mignon-Godefroy, K., Guillet, J., Butor, C., 1997. Laser scanning cytometry for the detection of rare events. Cytometry 27, 336-344.

Miller, P., Scholin, C.A., 1996. Identification of cultured Pseudonitzschia (Bacillariophyceae) using species specific LSU rRNAtargeted fluorescent probes and filter based whole-cell hybridisation. J. Phycol. 32, 646-655.

Miller, P., Scholin, C.A., 2000. On detection of Pseudo-nitzschia (Bacillariophyceae) species using whole-cell hybridization: sample fixation and stability. J. Phycol. 36, 238-250. 
Parsons, T., Maita, Y., Lalli, C., 1984. A manual of chemical and biological methods for seawater analysis. Pergamon.

Peperzak, L., Vrieling, E.G., Sandee, B., Rutten, T., 2000. Immuno flow cytometry in marine phytoplankton research. Sci. Mar. 64, $165-181$.

Rafuse, C., 2004. Effects of Physiological and Environmental Conditions on rRNA Probes for Two Species of Microalgae, Alexandrium ostenfeldii and A. tamarense. $\mathrm{Ph} \mathrm{D}$ Thesis, Dalhousie University, Halifax.

Raine, R., Mahony, J.O., McMahon, T., Roden, C., 1990. Hydrography and phytoplankton of waters off south-west Ireland. Estuar. Coastal Shelf Sci. 30, 579-592.

Reckermann, M., Colijn, F., 2000. Phytoplankton counting and biomass estimation procedures. In: Ring Test Round 1 Excercise Report. Phytoplankton assemblage analysis (BEQUALM WP 11), Büsum, Research and Technology Centre Westcoast of Kiel University, Kiel.

Reckermann, M., Colijn, F., Schilling, P., 2001. Phytoplankton counting and biomass estimation procedures. In: Ring Test Round 2 (RT 2001) Exercise Report. Phytoplankton assemblage analysis (BEQUALM WP 11), Büsum, Research and Technology Centre Westcoast of Kiel University, Kiel.

Savin, M., Martin, J., LeGresley, M., Giewat, M., Rooney-Varga, J., 2004. Plankton diversity in the Bay of Fundy as measured by morphological and molecular methods. Microbial. Ecol. 48, 5165.

Scholin, C.A., Buck, K.R., Britschgi, T., Cangelosi, G., Chavez, F.P., 1996. Identification of Pseudo-nitzschia australis (Bacillariophy- ceae) using rRNA-targeted probes and sandwich hybridization formats. Phycologia 35, 190-197.

Scholin, C.A., Miller, P., Buck, K., Chavez, F., Harris, P., Haydock, P., Howard, J., Cangelosi, G., 1997. Detection and quantification of Pseudo-nizschia australis in cultured and natural populations using LSU rRNA-targeted probes. Limnol. Oceanogr. 42, $1265-1272$.

Scholin, C.A., Marin, R., Miller, P., Doucette, G., Powell, C., Howard, J., Haydock, P., Ray, J., 1999. Application of DNA probes and a receptor binding assay for detection of Pseudo-nitzschia (Bacillariophyceae) species and domoic acid activity in cultured and natural samples. J. Phycol. 35, 1356-1367.

Schönhuber, W., Zarda, B., Eix, S., Rippka, R., Herdmann, M., Ludwig, W., Amann, R., 1999. In situ identification of cyanobacteria with horseradish peroxidase-labeled, rRNA-targeted oligonucleotide probes. Appl. Environ. Microbiol. 65, 1259-1267.

Töbe, K., Eller, G., Medlin, L.K., 2006. Automated detection and enumeration for toxic algae by solid-phase cytometry and the introduction of a new probe for Prymnesium parvum (Haptophyta: Prymnesiophyceae). J. Plankton Res., in press.

Utermöhl, H., 1958. Zur Vervollkommnung der quantitativen phytoplankton-methodik. Mitt. Int. Ver. Limnol. 9 (1-38) (in German).

Yamaguchi, M., 1992. DNA synthesis and the cell cycle in the noxious red-tide dinoflagellate Gymnodinium nagasakiense. Mar. Biol. 112, 191-198.

Yamaguchi, M., Itakura, S., Imai, I., Ishida, Y., 1995. A rapid and precise technique for enumeration of resting cysts of Alexandrium spp. (Dinophyceae) in natural sediments. Phycologia 34, 207-214. 